\title{
Diaporthe perjuncta Does Not Cause Phomopsis Cane and Leaf Spot Disease of Grapevine in Australia
}

\author{
B. Rawnsley and T. J. Wicks, South Australian Research and Development Institute, GPO Box 397, Adelaide, South \\ Australia, SA 5001; and E. S. Scott and B. E. Stummer, School of Agriculture and Wine, Waite Campus, The Uni-
} versity of Adelaide, PMB 1, Glen Osmond, South Australia, 5064

\begin{abstract}
Rawnsley, B., Wicks, T. J., Scott, E. S., and Stummer, B. E. 2004. Diaporthe perjuncta does not cause Phomopsis cane and leaf spot disease of grapevine in Australia. Plant Dis. 88:1005-1010.

In Australia, Diaporthe perjuncta (formerly known as Phomopsis taxon 1) and Phomopsis viticola (Phomopsis taxon 2) have been associated with Phomopsis cane and leaf spot of grapevine. Although $P$. viticola causes distinct leaf spots, as well as lesions on shoots and canes, the pathogenicity of $D$. perjuncta is relatively unknown. The pathogenicity of $D$. perjuncta and $P$. viticola was studied in relation to symptom expression and bud loss. Only P. viticola caused brownblack, longitudinal, necrotic lesions on stem tissue and leaf spots characteristic of the disease, whereas both $D$. perjuncta and $P$. viticola induced bleaching of dormant canes. Inoculation of dormant buds with $D$. perjuncta did not cause bud death. $D$. perjuncta and $P$. viticola were reisolated from inoculated tissue and into pure culture. D. perjuncta colonized the epidermis and cortex of the grapevine shoot but not the vascular tissue. D. perjuncta appears to be an endophyte, rather than a pathogen of grapevine.
\end{abstract}

Diaporthe perjuncta (formerly known as Phomopsis taxon 1) and Phomopsis viticola (Phomopsis taxon 2) have been associated with the disease Phomopsis cane and leaf spot of grapevine in Australia (16). The species are distinguished primarily on the basis of $\alpha$-conidia morphology and the presence of a teleomorph. Scheper et al. (25) identified $D$. viticola as the teleomorph of Phomopsis taxon 1 in Australia. However, Phillips (21) examined Diaporthe isolates from grapevines grown in Australia and Portugal and determined that they should be assigned to $D$. perjuncta rather than D. viticola, but he did not propose a name for the anamorph. The teleomorph of $P$. viticola is not known. Mostert et al. (19) characterized several taxa of Phomopsis associated with Phomopsis cane and leaf spot of grapevine and determined that delimitation of the species on the basis of morphology was unreliable. Molecular analysis of the internal transcribed spacer (ITS) regions confirmed Phomopsis taxon 2 as Phomopsis viticola and that it was genetically distinct from $D$. perjuncta (19).

Corresponding author: B. Rawnsley

E-mail: rawnsley.belinda@saugov.sa.gov.au

This project was supported by Australia's grapegrowers and winemakers, through their investment body, the Grape and Wine Research and Development Corporation, with matching funds from the Federal Government.

Accepted for publication 30 April 2004.

Publication no. D-2004-0712-04R

(C) 2004 The American Phytopathological Society
Historically, the earliest described symptoms of Phomopsis cane and leaf spot included failure of shoots to develop, dwarfed foliage, stunted shoots, and very small leaves on one arm of the vine (24). These observations were not truly characteristic of the disease because symptoms caused by $P$. viticola were confused with those due to other pathogens, such as Eutypa lata, in the same vine (17). It is now recognized that symptoms caused by $P$. viticola include distinct dark brown or black leaf spots with a yellow halo, and black longitudinal lesions on petioles and shoots leading to cracking of canes $(9,11,13,22,29)$. Elongated, black lesions also develop on the rachis, resulting in girdling that can cause cluster fall (23). $P$. viticola causes yield loss through weakening canes, fruit rot, and reduction in bunch set $(13,23)$, and has been associated with yield loss of up to $30 \%$ in Macedonia (2) and the United States of America (10,23). In Australia, there are no records of yield loss, although fungicides can reduce the incidence of disease $(4,26)$.

Although the pathogenicity of $P$. viticola to grapevines has been demonstrated (10), the role of $D$. perjuncta as a pathogen is poorly understood. Infection by $D$. perjuncta is assumed to be less damaging than $P$. viticola, although Melanson et al. (15) suggested that $D$. perjuncta may be responsible for bud loss. There are few reports of $D$. perjuncta causing distinct visual symptoms on grapevine. Mostert et al. (18) observed light brown, small lesions on green excised shoots inoculated with $D$. perjuncta, but could not distinguish between $P$. viticola and $D$. perjuncta based on lesion length. D. perjuncta has not been isolated from leaf spots and rarely is encountered on diseased material from vineyards affected by Phomopsis cane and leaf spot (19). Scheper et al. (25) described symptoms associated with the teleomorph as zone lines on bleached spurs. Based on stem inoculations, Mostert et al. (19) suggested that $D$. perjuncta was nonpathogenic to grapevine. However, only one isolate of $D$. perjuncta was tested and further tests are warranted to confirm the nonpathogenicity of the fungus.

This study was undertaken to evaluate the pathogenicity of isolates of $D$. perjuncta from grapevine and to compare the susceptibility of a range of cultivars to infection by $D$. perjuncta and $P$. viticola using excised grapevine shoots. The role of D. perjuncta in bud loss also was investigated.

\section{MATERIALS AND METHODS}

Fungal isolation. Bleached canes with pycnidia were collected in autumn and winter from a number of vineyards in South Australia naturally infected with $D$. perjuncta and $P$. viticola. Canes were incubated in dark, moist conditions at $15^{\circ} \mathrm{C}$ for at least 1 week to induce sporulation. Conidia, exuded from pycnidia, were diluted in sterile, double-distilled $\mathrm{H}_{2} \mathrm{O}$, then transferred aseptically to potato dextrose agar (PDA) and incubated for 7 days in a cycle of $12 \mathrm{~h}$ of light (Philips TLD 18W/33 3F, 380 to $780 \mathrm{~nm}$ and near ultraviolet) at $22^{\circ} \mathrm{C}$ and $12 \mathrm{~h}$ of darkness at $16^{\circ} \mathrm{C}$. Pure cultures were obtained by transferring mycelium from germinating conidia to new PDA plates. Cultures sporulated after 7 and 21 days for $P$. viticola and D. perjuncta, respectively. Isolates were identified as $D$. perjuncta or $P$. viticola on the basis of conidial morphology (16). P. viticola taxon 3 (DAR69458) was provided by M. Priest, Agricultural Scientific Collections Unit, NSW Agriculture, Orange, Australia.

Preparation of spore suspension. Isolates of $D$. perjuncta and $P$. viticola (Table 1) were chosen based on geographical origin and the presence of adequate quantities of conidia and mycelium needed for inoculations. Carnation leaf agar (CLA) was used to produce pycnidia of $D$. perjuncta and $P$. viticola in vitro (25). Pieces of carnation leaf were surface sterilized in $0.5 \mathrm{M}$ sodium hypochlorite $(\mathrm{NaOCl})$ for 
$30 \mathrm{~s}$, rinsed in sterile water, then autoclaved at $121^{\circ} \mathrm{C}$ for $20 \mathrm{~min}$. Leaf pieces $(10$ by $5 \mathrm{~mm}$ ) were placed on the surface of $1.2 \%$ water agar (WA) in petri dishes. Mycelial plugs from cultures on PDA (10 by 10 $\mathrm{mm}$ ) were placed onto CLA and incubated as above. For each isolate, several cirrhi were suspended in sterile, double-distilled water (28) and the concentration adjusted to $10^{4}$ to $10^{6}$ conidia/ml using a haemocytometer.

To assess conidial germination, five 10$\mu \mathrm{l}$ droplets of spore suspension of each isolate were placed on $1.2 \%$ WA and incubated overnight as described. Percent germination was examined after 10 to $12 \mathrm{~h}$.

Assessment of pathogenicity of $D$. perjuncta. To compare symptoms caused by $D$. perjuncta and $P$. viticola, excised shoots were inoculated with mycelium in the glasshouse. Green, 6-month-old terminal shoots of Vitis vinifera (cv. Sultana), 0.5 to $1.2 \mathrm{~cm}$ in diameter and cut to $30 \mathrm{~cm}$ long, were pruned from healthy vines in a vineyard at the Waite Agricultural Research Institute, South Australia. All leaves and tendrils were removed from the shoots prior to spraying with $70 \%$ ethanol. Shoots were placed in 500-ml plastic jars containing $200 \mathrm{ml}$ of tap water, so that the lower half of the shoot was submerged. Eight replicate shoots per treatment were wounded $10 \mathrm{~cm}$ from the top of the shoot by removing the cortex with a 4-mm-diameter cork borer. Shoots were inoculated with 4-mm-diameter plugs from 14-dayold cultures on PDA: D. perjuncta isolates A223.1, H307, L406, and $\mathrm{J} 5$, and $P$. viticola isolates C603, P712, 902.4, and
M851. Control shoots received an uncolonized PDA plug. Each wound was sealed with parafilm and shoots were maintained in a glasshouse at $25^{\circ} \mathrm{C}$ with natural light. The water was replaced every second day. Lesion length (minus diameter of initial wound) was measured 14 days after inoculation. Pieces of tissue, approximately 5 by $5 \mathrm{~mm}$, were excised from the margin of lesions and surface sterilized with $0.5 \%$ $\mathrm{NaOCl}$ for $30 \mathrm{~s}$, followed by 1-min rinses in sterile water. Sections then were plated on PDA and incubated for 3 days at 16 and $22^{\circ} \mathrm{C}$ in the dark and light, respectively, as described. Re-isolation was attempted from four shoots per treatment.

In addition, the pathogenicity of $11 \mathrm{D}$. perjuncta isolates (A223.1, A223.2, H307, L406, J4, J5, L427, L424, T100, T101, and M860), 1 P. viticola isolate (M831.1), and 1 Phomopsis taxon 3 isolate (DAR69458) was compared by inoculating eight replicate excised shoots (cv. Sultana) in a separate experiment. Shoots were wounded as described above and inoculated with 7day-old mycelium. Controls were inoculated with uncolonized PDA plugs.

The susceptibility of selected grapevine cultivars was assessed by inoculating green, 6-month-old shoots of four red grape cultivars (Shiraz, Grenache, Merlot, and Cabernet Sauvignon) and three white grape cultivars (Semillon, Chardonnay, and Sauvignon Blanc) as described above with $D$. perjuncta, $P$. viticola, and sterile PDA plugs (Table 1). Four excised shoots of Semillon were selected for re-isolation of isolate A223.1 from both necrotic tissue and from asymptomatic tissue 20 to 40 $\mathrm{mm}$ distant from the point of inoculation.
Selected shoots were examined microscopically to investigate colonization of host tissue by $D$. perjuncta and $P$. viticola. Tissue samples were taken 2 weeks after inoculation at the site of wounding and at intervals of $10 \mathrm{~mm}$ above and below the point of inoculation from three replicate excised shoots (cv. Sultana) inoculated with $D$. perjuncta isolates A223.2, J5, and T101, P. viticola isolate M831.1, or PDA. In addition, shoots (cv. Grenache) inoculated with $D$. perjuncta isolate A223.1 or P. viticola isolate M851 were examined. Sections up to $40 \mathrm{~mm}$ from the margin of the lesion were assessed. Fresh shoot tissue was cut into 10$\mathrm{mm}$ sections and submerged in $25 \mathrm{ml}$ of 1 $\mathrm{M} \mathrm{KOH}$ in a McCartney bottle for a minimum of $30 \mathrm{~min}$ at room temperature, followed by three rinses in sterile, doubledistilled $\mathrm{H}_{2} \mathrm{O}$ for approximately $5 \mathrm{~min}$ each (14). The stain solution, $0.05 \%$ aniline blue (dye CI \#42755, BDH) in 0.067 $\mathrm{M} \mathrm{K}_{2} \mathrm{HPO}_{4}, \mathrm{pH} 9.0$, was prepared at least $2 \mathrm{~h}$ before use. Tissue was hand sectioned, either as a cross-section of the shoot or a longitudinal section of the epidermis, and mounted on glass slides containing several drops of stain solution. Tissue was examined immediately with a UV microscope (BP495 exciter: barrier fluorescence filters) at $\times 100$ magnification.

Colonization of dormant buds. To examine the effect of $D$. perjuncta on budburst, two inoculation methods were used to facilitate rapid colonization of the bud by either penetration through a wound site or penetration through a prematurely created leaf scar. Dormant grapevine cuttings

Table 1. Isolates of Diaporthe perjuncta, Phomopsis viticola, and Phomopsis taxon 3 used in pathogenicity experiments, cultivars inoculated (Inoc.), and corresponding inoculation method

\begin{tabular}{|c|c|c|c|c|c|c|c|c|c|}
\hline \multirow[b]{2}{*}{ Isolate } & \multirow[b]{2}{*}{ Species } & \multirow[b]{2}{*}{ Site $^{w}$} & \multicolumn{6}{|c|}{ Experiment number, cultivar, method } & \multirow[b]{2}{*}{ Microscopy $^{y}$} \\
\hline & & & $\begin{array}{l}\text { 1, Sultana, } \\
\text { shoot } \\
\text { mycelium }\end{array}$ & $\begin{array}{l}\text { 2, Sultana, } \\
\text { shoot } \\
\text { mycelium }\end{array}$ & $\begin{array}{l}\text { 3, various } \\
\text { cvs., shoot } \\
\text { mycelium }^{x}\end{array}$ & $\begin{array}{l}\text { 4, Shiraz, } \\
\text { bud } \\
\text { mycelium }\end{array}$ & $\begin{array}{l}\text { 5, Chardonnay, } \\
\text { bud \& leaf } \\
\text { conidia }\end{array}$ & $\begin{array}{l}\text { 6, Shiraz, } \\
\text { bud } \\
\text { conidia }\end{array}$ & \\
\hline A223.1 & D. perjuncta & Ashton, SA & Inoc. & Inoc. & Inoc. & Inoc. & $\ldots$ & $\ldots$ & Inoc. \\
\hline A223.2 & D. perjuncta & Ashton, SA & $\ldots$ & $\ldots$ & $\ldots$ & $\ldots$ & $\ldots$ & $\ldots$ & Inoc. $^{\mathrm{z}}$ \\
\hline H307 & D. perjuncta & Summertown, SA & Inoc. & Inoc. & $\ldots$ & $\ldots$ & Inoc. & $\ldots$ & $\ldots$ \\
\hline L406 & D. perjuncta & Carey Gully, SA & Inoc. & Inoc. & $\ldots$ & $\ldots$ & $\ldots$ & Inoc. & $\ldots$ \\
\hline $\mathrm{J} 4$ & D. perjuncta & Mount Compass, SA & $\ldots$ & Inoc. & $\ldots$ & $\ldots$ & $\ldots$ & $\ldots$ & $\ldots$ \\
\hline J5 & D. perjuncta & Mount Compass, SA & Inoc. & Inoc. & $\ldots$ & $\ldots$ & $\ldots$ & $\ldots$ & Inoc. \\
\hline L427 & D. perjuncta & Lenswood, SA & $\ldots$ & Inoc. & $\ldots$ & $\ldots$ & $\ldots$ & $\ldots$ & $\ldots$ \\
\hline $\mathrm{L} 424$ & D. perjuncta & Lenswood, SA & $\ldots$ & Inoc. & $\ldots$ & $\ldots$ & $\ldots$ & $\ldots$ & $\ldots$ \\
\hline $\mathrm{T} 100$ & D. perjuncta & McLaren Vale, SA & $\ldots$ & Inoc. & $\ldots$ & $\ldots$ & $\ldots$ & $\ldots$ & $\ldots$ \\
\hline T101 & D. perjuncta & Langhorne Creek, SA & $\ldots$ & Inoc. & $\ldots$ & $\ldots$ & $\ldots$ & $\ldots$ & Inoc. \\
\hline M860 & D. perjuncta & Margaret River, WA & $\ldots$ & Inoc. & $\ldots$ & $\ldots$ & $\ldots$ & $\ldots$ & $\ldots$ \\
\hline $51 \mathrm{C} .1$ & D. perjuncta & Coonawarra, SA & $\ldots$ & $\ldots$ & $\ldots$ & $\ldots$ & Inoc. & $\ldots$ & $\ldots$ \\
\hline M831.1 & P. viticola & Wagga Wagga, NSW & $\ldots$ & Inoc. & $\ldots$ & $\ldots$ & $\ldots$ & $\ldots$ & Inoc. \\
\hline M851 & P. viticola & McLaren Vale, SA & Inoc. & $\ldots$ & Inoc. & $\ldots$ & $\ldots$ & $\ldots$ & Inoc. \\
\hline LR10T6 & P. viticola & Lenswood, SA & $\ldots$ & $\ldots$ & $\ldots$ & $\ldots$ & Inoc. & Inoc. & $\ldots$ \\
\hline C603 & P. viticola & Coonwarra, SA & Inoc. & $\ldots$ & $\ldots$ & $\ldots$ & $\ldots$ & $\ldots$ & $\ldots$ \\
\hline P712 & P. viticola & Padthaway, SA & Inoc. & $\ldots$ & $\ldots$ & $\ldots$ & $\ldots$ & $\ldots$ & $\ldots$ \\
\hline 902.4 & P. viticola & Robinvale, Vic & Inoc. & $\ldots$ & $\ldots$ & Inoc. & $\ldots$ & $\ldots$ & $\ldots$ \\
\hline DAR69458 & Phomopsis taxon 3 & Yarra Valley, NSW & $\ldots$ & Inoc. & $\ldots$ & $\ldots$ & $\ldots$ & $\ldots$ & $\ldots$ \\
\hline
\end{tabular}

${ }^{\mathrm{w}} \mathrm{SA}=$ South Australia, WA = Western Australia, Vic $=$ Victoria, NSW = New South Wales.

${ }^{x}$ Vitis vinifera cultivars: Shiraz, Grenache, Merlot, Cabernet Sauvignon, Semillon, Chardonnay, and Sauvignon Blanc.

${ }^{y}$ Tissue samples of excised grapevine shoots were hand sectioned, submerged in $1 \mathrm{M} \mathrm{KOH}$ for 30 min, and stained with $0.05 \%$ aniline blue dye in $0.067 \mathrm{M}$ $\mathrm{K}_{2} \mathrm{HPO}_{4}$, $\mathrm{pH} 9.0,2$ weeks after inoculation with $D$. perjuncta or $P$. viticola.

${ }^{\mathrm{z}} \mathrm{Six}$ isolates under microscopy. 
were obtained from the Vine Improvement Centre, Monash, South Australia. Roots were induced on 30 grapevine cuttings approximately $40 \mathrm{~cm}$ long (cv. Shiraz) by submerging in water for $24 \mathrm{~h}$ at $4^{\circ} \mathrm{C}$, then in water containing $10 \mathrm{ml}$ of sodium hypochlorite for a further $24 \mathrm{~h}$. Following additional soaking in clean water for $24 \mathrm{~h}$, each cutting was dipped in indole-3-butyric acid (IBA; Sigma-Aldrich, St. Louis) at $2 \mathrm{~g} /$ liter for $40 \mathrm{~s}$. Cuttings were transferred into water-soaked rock wool blocks ( 40 by $40 \mathrm{~mm}$ ) and planted in $20-\mathrm{cm}$-diameter pots containing University of California (UC) potting mix (1) and $10 \mathrm{~g}$ of Osmocote slow-release granular fertilizer (Arthur Yates and Co. Ltd, Homebush, NSW, Australia).

After 10 months in the greenhouse, 0.7$\mathrm{mm}$-diameter lignified shoots on each vine were prepared for inoculation. Grapevine plants were at the stage of leaf fall. Green leaves were removed and dormant buds retained. Ten plants were inoculated with D. perjuncta isolate A223.1, P. viticola isolate 902.4, or a PDA plug (control).

Of the 10 plants receiving each treatment, 4 were wounded with a scalpel and 6 were wounded by leaf removal. For the first method, 16 dormant buds were inoculated among the four plants. The number of buds inoculated was not the same per plant. A wound (approximately $5 \mathrm{~mm}$ wide and $3 \mathrm{~mm}$ deep) was made with a scalpel on the lignified shoot below each dormant bud. A mycelial plug of the test isolate was taken from the margin of a 7-day-old colony on PDA, inserted into the wound, and sealed with parafilm. Controls were treated with a sterile PDA plug. For the second method, 20 buds among the six plants were inoculated. A premature leaf scar beneath the bud was created by detaching the petioles by hand (27) and inoculated as above. Plants were placed in a shade house and maintained until budburst for at least 8 weeks. The percentage of buds burst, bleaching, and development of pycnidia were recorded over 8 weeks, commencing at budburst. Four plants from each treatment were selected arbitrarily for re-isolation of the fungi.

Infection of buds and leaves. To determine if infection by $D$. perjuncta conidia caused bud death and to clarify symptom expression, eight replicate mature grapevine plants were inoculated in the glasshouse with one of the following four treatments: D. perjuncta isolate $\mathrm{H} 307$ at $10^{4} \alpha$ conidia/ml, D. perjuncta isolate $51 \mathrm{C} .1$ at $10^{6} \alpha$-conidia $/ \mathrm{ml}, \quad P$. viticola isolate LR10T6 at $10^{6}$ conidia/ml $(50 \% \alpha$ - and $\beta$ conidia), and sterile, double-distilled $\mathrm{H}_{2} \mathrm{O}$ as a control. Plants were pruned 4 weeks prior to inoculation and then to two green shoots 1 day before treatment. The average length was 26.2 and $17.7 \mathrm{~cm}$ for bud and leaf-inoculated shoots, respectively. On one shoot, the bud at the basal node was inoculated with a $10-\mu l$ droplet of spore suspension or sterile water. On the other shoot, conidial suspension was applied to the leaf at the first node using a Jet-Pak Blacktown, NSW, Australia). Clear plastic bags were placed over the shoots for $48 \mathrm{~h}$ during this time with a datalogger (Tinytalk II; Hastings, NSW, Australia). Buds, leaves, and internodes of inoculated shoots were rated for disease severity weekly for 8 weeks. A 0-to-4 scale was used based on the Barratt and Horsfall rating system, modified from Phillips (20), where $0=$ no sign of disease, 1 = few lesions covering no more than $25 \%$ of leaf or internode, $2=$ many lesions covering 25 to $50 \%$ of leaf or internode, $3=$ over $50 \%$ leaf or internodal area severely scarred or necrotic, and $4=$ death of shoot or bud (no shoots emerged). Re-isolations were made from dissected buds and leaves 8 weeks after inoculation as described. The woody canes were placed on moist paper towel in a sealed container at $15^{\circ} \mathrm{C}$ in darkness to induce production of pycnidia.

Dormant buds were inoculated to determine if $D$. perjuncta causes delayed budburst, or bud death, and to assess symptoms on developing shoots. Eight dormant cuttings of grapevine (cv. Shiraz; Vine Improvement Centre) comprising three buds each were inoculated with a $50-\mu \mathrm{l}$ droplet of $10^{6} \alpha$-conidia $/ \mathrm{ml}$. The surface of the bud was inoculated with $D$. perjuncta isolate L406, P. viticola isolate LR10T6, or sterile, double-distilled $\mathrm{H}_{2} \mathrm{O}$. In addition, the entire epidermis of eight dormant cutperjuncta isolate L406 $\left(10^{6} \alpha\right.$-conidia/ml $)$ as before. The cuttings were incubated in a growth room at 19 and $14^{\circ} \mathrm{C}$ in the light and dark, respectively, and enclosed in spray power unit (Wattyl Australia Pty Ltd, and the temperature in the bags measured tings was sprayed with a suspension of $D$.

clear plastic bags with a datalogger, as above. Each bud was assessed for stage of development, shoot length, and disease severity weekly over 8 weeks. Disease severity was assessed (20) and the Modified Eichhorn-Lorenz system was used to determine stage of development, such that $0=$ death of a dormant or developing bud; 1 = winter bud (dormant); 2 = bud swell; 3 = woolly bud, brown bud visible; 4 = green tip, first leaf tissue visible (budburst); and thereafter, $5=$ shoot (14).

Statistical analyses. Data were transformed to give a normal sampling distribution and $\log$ transformation values were subjected to analysis of variance (ANOVA) using the Statistix statistical package (version 7; Analytical Software, Tallahassee, FL). Means were separated by the least significant difference test at $P=0.05$.

\section{RESULTS}

Pathogenicity of $\boldsymbol{D}$. perjuncta. Shoots inoculated with $P$. viticola generally were weaker and paler in color than controls and those inoculated with $D$. perjuncta. Three days after inoculation with $P$. viticola, browning or discoloration of tissue at the wound site was observed in most excised shoots. Shoots inoculated with $P$. viticola developed dark brown or black, longitudinal, dry lesions that resembled symptoms characteristic of Phomopsis cane and leaf spot in the vineyard. P. viticola caused lesions up to $41 \mathrm{~mm}$ long (mean, $11 \mathrm{~mm}$ ), but the length of lesions produced by the four isolates was highly variable (Fig. 1). Typically, bleaching was observed on shoots approximately 12 days after inoculation.

Two weeks after inoculation, most shoots inoculated with $D$. perjuncta remained green and turgid with slight, dark

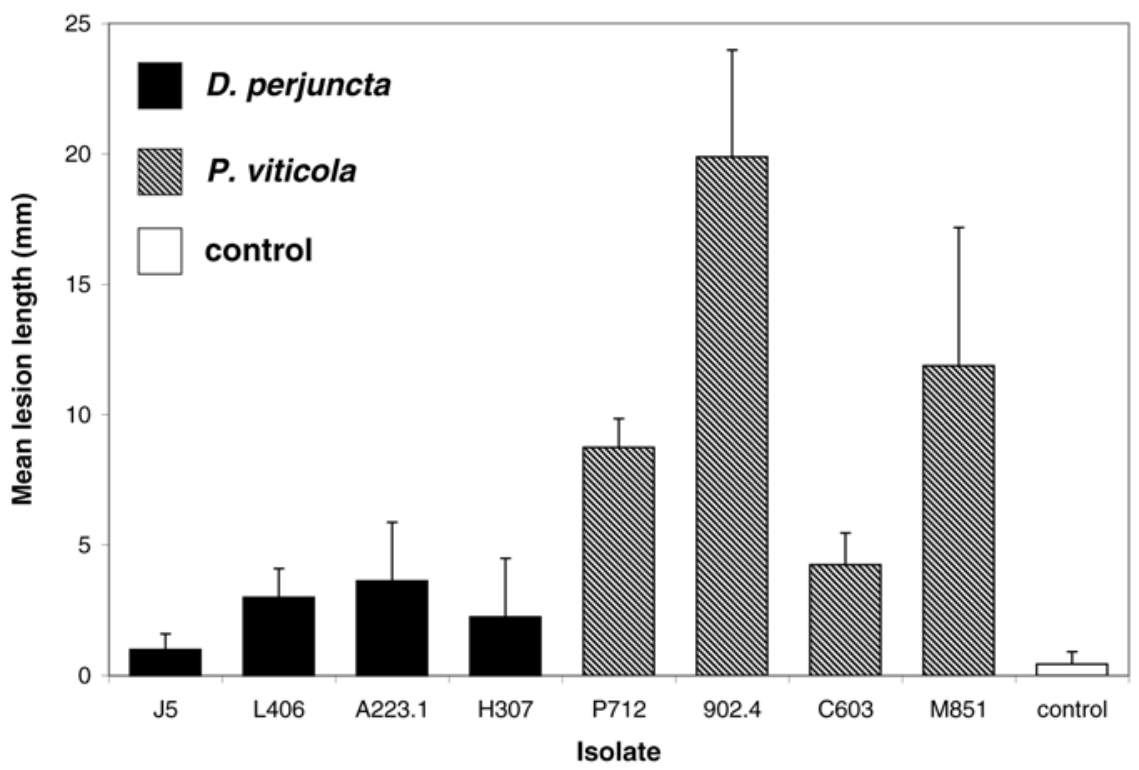

Fig. 1. Average lesion length (mm) produced on excised, green shoots (Vitis Vinifera cv. Sultana) 2 weeks after inoculation with Diaporthe perjuncta, Phomopsis viticola, or potato dextrose agar (control). Vertical bars represent standard error of the means. 
green discoloration and minor lesions around the wound site. Pycnidia and distinct narrow lines similar in appearance to that of a black marker pen (zone lines) were observed on two shoots inoculated with $D$. perjuncta. Lesion length did not differ among isolates of $D$. perjuncta $(P=$ 0.565). Control shoots remained green and turgid and there was little or no discoloration on around the wound site. $D$. perjuncta and $P$. viticola were re-isolated from tissue taken from the margin of the brown areas on four replicate shoots. Isolation from the control shoots yielded various fungi, including Aspergillus spp., Penicillium spp., and yeasts. Neither Pho-

Table 2. Mean lesion length on excised green shoots (Vitis vinifera cv. Sultana) 2 weeks after inoculation with mycelium of 11 isolates of Diaporthe perjuncta, 1 isolate each of Phomopsis viticola and Phomopsis taxon 3, and potato dextrose agar (control) ${ }^{\mathrm{y}}$

\begin{tabular}{llcc}
\hline & & \multicolumn{2}{c}{${\text { Lesion length }(\mathbf{m m})^{\mathbf{z}}}$} \\
\cline { 3 - 4 } Treatment & Isolate & Mean & \pm SE \\
\hline D. perjuncta & T101 & $10.4 \mathrm{~b}$ & 2.8 \\
D. perjuncta & L427 & $6.6 \mathrm{bc}$ & 3.3 \\
D. perjuncta & A223.2 & $6.1 \mathrm{bcd}$ & 2.7 \\
D. perjuncta & J5 & $5.6 \mathrm{bcde}$ & 3.1 \\
D. perjuncta & T100 & $4.3 \mathrm{cde}$ & 1.1 \\
D. perjuncta & L406 & $3.3 \mathrm{cde}$ & 1.3 \\
D. perjuncta & L424 & $3.1 \mathrm{cde}$ & 1.5 \\
D. perjuncta & A223.1 & $3.0 \mathrm{cde}$ & 0.7 \\
D. perjuncta & H307 & $2.0 \mathrm{cde}$ & 0.9 \\
D. perjuncta & J4 & $0.7 \mathrm{de}$ & 0.4 \\
D. perjuncta & M860 & $0.6 \mathrm{de}$ & 0.5 \\
P. viticola & M831.1 & $23.0 \mathrm{a}$ & 4.4 \\
Phomopsis taxon 3 & DAR69458 & $0.1 \mathrm{e}$ & 0.1 \\
Control & $\ldots$ & $0.9 \mathrm{cde}$ & 0.4 \\
\hline
\end{tabular}

${ }^{y}$ Mean lesion length based on eight replicate excised green shoots per treatment.

${ }^{\mathrm{z}} \mathrm{SE}=$ standard error. Means within a column followed by different letters are significantly different $(P=0.05)$ based on least significant difference.

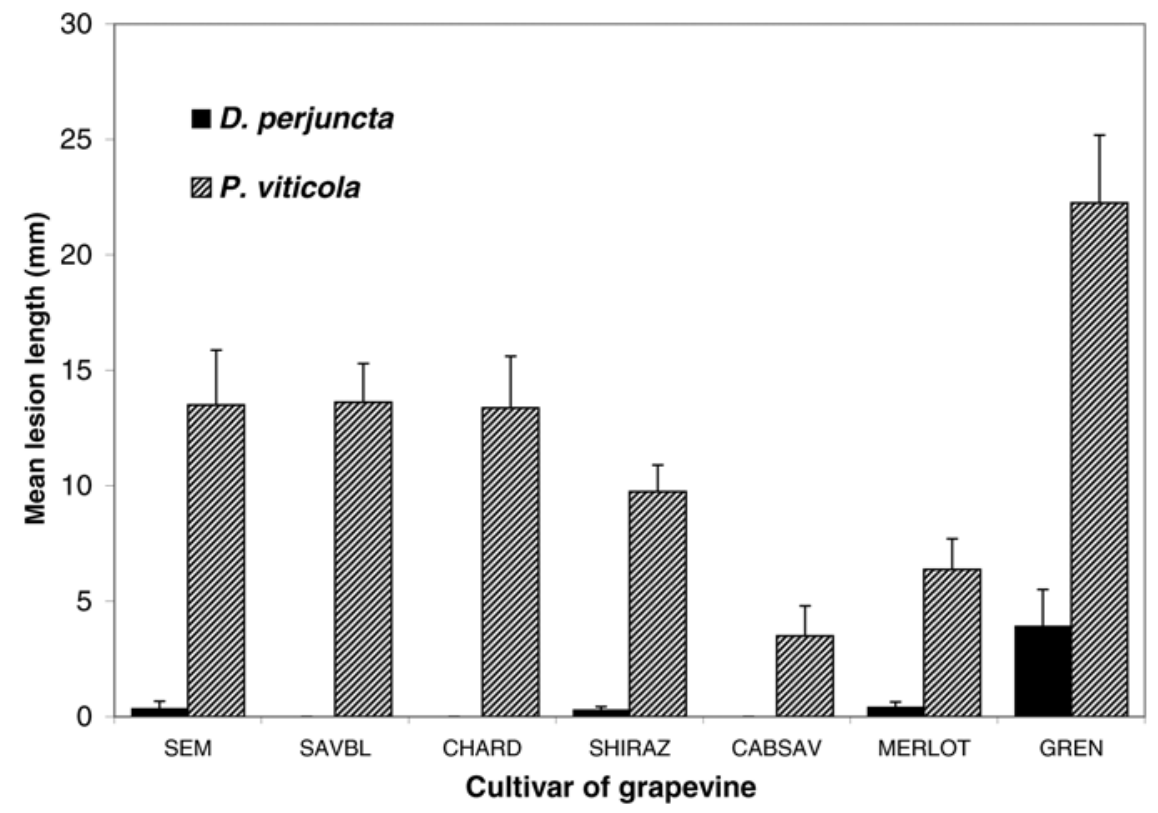

Fig. 2. Lesion length on excised green shoots of seven grapevine cultivars, Semillon (SEM), Sauvignon Blanc (SAVBL), Chardonnay (CHARD), Shiraz (SHIRAZ), Cabernet Sauvignon (CABSAV), Merlot (MERLOT), and Grenache (GREN) 2 weeks after inoculation with Diaporthe perjuncta isolate A223.1 or Phomopsis viticola isolate M851. Values are means of eight replicates per treatment. Shoots inoculated with potato dextrose agar (control) did not produce lesions. Vertical bars represent standard error of the means. as the longest lesion caused by $D$. perjuncta. In addition, $P$. viticola produced lesions that were wider (approximately 5 $\mathrm{mm}$ wide) than those produced by isolates of $D$. perjuncta (approximately 1 to $2 \mathrm{~mm}$ wide). Shoots inoculated with $P$. viticola were unhealthy and pale in color. As above, lesions did not develop on control shoots or those inoculated with Phomopsis taxon 3. D. perjuncta and P. viticola were recovered from the margin of the lesions in the appropriate inoculated shoots, and also from asymptomatic tissue approximately 3 $\mathrm{cm}$ from the wound.

$D$. perjuncta caused significantly smaller lesions than did $P$. viticola $(P=$ $0.001)$ on the various cultivars assessed. $P$. viticola caused dark brown or black, longitudinal lesions of similar length, severity, and width on cvs. Semillon, Sauvignon Blanc. and Chardonnay, whereas lesions on cvs. Shiraz, Merlot, and Cabernet Sauvignon were less severe (Fig. 2). ANOVA and comparison of means showed that lesions were significantly longer $(P=$ 0.011 and 0.000 ) on Grenache than on the other cultivars tested when data for $D$. perjuncta and $P$. viticola was analyzed separately. In addition, pycnidia developed on bleached sections of shoots of cv. Grenache inoculated with $P$. viticola. D. perjuncta and $P$. viticola were re-isolated from all inoculated shoots tested.

Microscopic examination of tissue inoculated with $D$. perjuncta revealed hyphae in the intercellular spaces of the cortex but not in the xylem and phloem. Tissue of excised green shoots inoculated with $D$. perjuncta was darkened at the site of inoculation, although cells approximately $10 \mathrm{~mm}$ from the wound were healthy. In comparison, lesions caused by $P$. viticola M851 and M831.1 extended along the shoot, with the hyphae appearing as a subcuticular mass. However, the cortical cells were intact and hyphal growth was intercellular. At the site of inoculation, mycelial growth was abundant and cell arrangement was disrupted. Tissue that appeared healthy $40 \mathrm{~mm}$ away from the site of inoculation was examined and hyphae observed under the cuticle. Single hyphae were observed intercellularly, but were not associated with discoloration or cell death. No hyphae were observed in vascular cells or the pith. Hyphae were not observed in control shoots, but cells were disrupted at the wound and cortical cells darkened. Darkening of cells in the control shoots resembled that caused by $D$. perjuncta at the point of inoculation. Callose deposits were observed near the wound and in the epidermal layer in tissue inoculated with $P$. viticola, but were not evident in control shoots.

Colonization of dormant buds. Twelve weeks after inoculation with $D$. perjuncta, all lignified shoots were bleached and bore pycnidia, particularly around the nodes and sites of inoculation. Similarly, $91.5 \%$ of 
spurs inoculated with $P$. viticola were bleached and $90 \%$ bore pycnidia. The bleaching symptoms were typical of those observed in the field, and bleaching alone could not be used to visually differentiate between $P$. viticola and $D$. perjuncta. One lignified shoot inoculated with PDA was slightly bleached, but no pycnidia were present. In general, budburst percentage was poor regardless of treatment. $D$. perjuncta and $P$. viticola were isolated readily from pycnidia on inoculated grapevine plants.

Infection of buds and leaves. There was no evidence that $D$. perjuncta or $P$. viticola caused bud death, because most buds remained healthy or burst and internal tissue of dissected buds was intact and green. All shoots that developed on inoculated and control plants were healthy.

Small necrotic leaf spots (approximately $1 \mathrm{~mm}$ in diameter) surrounded by a distinct yellow halo developed 3 weeks after leaves were inoculated with $P$. viticola. The leaf spots developed on less than $25 \%$ of the leaf area. After 4 to 5 weeks, dark-brown, longitudinal lesions developed on the corresponding petioles. $P$. viticola was reisolated from the margin of several leaf spots but not from asymptomatic tissue. Control vines and those inoculated with $D$. perjuncta remained symptomless. D. perjuncta was re-isolated from inoculated grapevine tissue.

Following inoculation of dormant buds with conidia, neither $D$. perjuncta nor $P$. viticola had a significant effect on bud development $(P=0.07)$. By week 2, 100\% of terminal buds (bud three) burst while most basal buds (bud one) remained dormant throughout the assessment period, regardless of treatment. Shoots from bud three generally were longer and healthier than those from other buds. Shoots developing from buds inoculated with $D$. perjuncta were similar in appearance and length to those inoculated with $P$. viticola (data not shown). Three weeks after inoculation, brown spots approximately $1 \mathrm{~mm}$ in diameter with a characteristic yellow halo were observed on leaves on plants inoculated with P. viticola. By week 5, six dormant buds on plants inoculated with $P$. viticola turned brown and died. $P$. viticola was isolated from five of these dead buds. ANOVA indicated that disease severity on developing shoots did not differ significantly $(P=0.73)$ between replicates or treatments.

\section{DISCUSSION}

$D$. perjuncta was not pathogenic to grapevine shoots or buds. Pathogenicity tests showed that failure of buds to burst, stunted shoots, and leaf or shoot symptoms associated with Phomopsis cane and leaf spot were not caused by D. perjuncta. In the present study, D. perjuncta isolates from various viticultural regions of Australia were consistently less virulent than the isolates of $P$. viticola tested. Excised shoots inoculated with mycelium of $P$. viticola developed dark brown or black, longitudinal lesions similar to those produced by natural infection in the field. However, there was large variation among isolates of $P$. viticola tested. Koch's postulates were fulfilled by inoculation of grapevine plants and re-isolation of $D$. perjuncta and $P$. viticola from inoculated shoots. Mostert et al. (18) reported that $P$. viticola and $D$. perjuncta could not be distinguished on the basis of lesion length, but we demonstrated that colonization by $P$. viticola caused longer and more severe lesions on excised shoots than did D. perjuncta. There are limited reports on susceptibility of grape cultivars to $P$. viticola and $D$. perjuncta. Gubler and Leavitt (11) reported that cv. Grenache was highly susceptible to Phomopsis cane and leaf spot in years with wet springs. Furthermore, cv. Concord often is regarded as highly susceptible $(5,6,24)$. The pathogenicity studies undertaken here suggest that inoculation of excised green shoots may be suitable for determining pathogen variability and cultivar susceptibility.

Both D. perjuncta and $P$. viticola induced bleaching on grapevine, and it was not possible to distinguish between the two fungi based on this symptom. Although bleached canes in winter often are associated with the disease, bleaching can be attributed to physical damage, extremes of weather, Botrytis cinerea, and saprophytic pycnidium-producing fungi (3). Nevertheless, the presence of bleaching and reisolation of both fungi from pycnidia indicated a physiological change in grapevine tissue. This can be associated with fungal colonization of the epidermal cells and developing pycnidia, forcing the layer of epidermal cells away from the cortex (13).

D. perjuncta did not cause bud death, delay in bud burst, or stunted shoots. However, the inoculation methods used in the study were effective in facilitating fungal infection, as evidenced by bleaching and leaf symptoms. In general, bud burst percentage was low in all treatments, and studies of the effects of fungal colonization on bud development were inconclusive. Uddin and Stevenson (27) reported a Phomopsis sp. causing rapid development of peach shoot blight after inoculation of wounded dormant buds and breaking buds, and suggested that some Phomopsis spp. on woody plants may invade the shoot through the young, exposed tissue of the bud. $P$. viticola is known to overwinter in dormant buds (13), but it is unknown if natural colonization of buds can result in direct infection of new shoots. Perithecia of $D$. perjuncta have been observed protruding from naturally infected unburst buds in in vitro conditions, indicating that the fungus either may colonize buds directly (15) or simply overwinter in bud scales. It is possible that rapid develop- ment of buds on newly propagated canes in the present study did not allow sufficient time for $D$. perjuncta or $P$. viticola to colonize and cause bud death under glasshouse conditions.

$D$. perjuncta colonized the epidermis of excised green grapevine shoots but not the vascular tissue. Likewise, $P$. viticola was restricted to the epidermal and cortical cells, with no growth into the vascular bundle. A large mass of subcuticular hyphae of $P$. viticola was evident beneath necrotic lesions. In addition, hyphal masses were concentrated on the proximal side of the inoculated point, with lesions formed longitudinally along the side of the shoot in either direction. Microscopic examination indicated that hyphal growth caused disruption by physically forcing the cells apart rather by intracellular growth. Therefore, eventual cracking of shoots infected with $P$. viticola may be attributed in part to the disruption of host cells. The findings support an earlier report that $P$. viticola does not invade healthy xylem tissue and is not associated with dieback of grapevine (17). In contrast, other Phomopsis spp., such as $P$. vaccinii, cause dieback of shoots resulting from necrosis and collapse of parenchyma cells and vascular tissue after invading the cortex (7).

The findings of this study clarify that $D$. perjuncta is not associated with Phomopsis cane and leaf spot in Australia. Rather, the limited pathogenicity of D. perjuncta on grapevine suggests that it is endophytic. $D$. perjuncta grew inconspicuously within the tissue of grapevine without causing symptoms or apparent injury. D. perjuncta was detected only by staining, or when pycnidia erupted through the epidermis. The degree of mutualism between the host and endophyte is dependent on the plant environment (12), and it is possible for endophytic fungi to become pathogenic when the host plant is weakened. Hence, further studies are needed to assess whether stress on the plant influences mycelial growth and the ability of the fungus to cause harm under a range of environmental conditions.

\section{ACKNOWLEDGMENTS}

We thank D. Partington (BiometricsSA, Adelaide, South Australia) for assistance with statistical analysis and A. J. L. Phillips for helpful advice during this study.

\section{LITERATURE CITED}

1. Baker, K. F. 1957. The U.C. System for Producing Healthy Container-Grown Plants. University of California Press, Berkeley.

2. Baltovski, B. 1980. A study of the dead-arm disease of grapevines caused by the fungus Phomopsis viticola Sacc. Ph.D. thesis, Doctor in Agricultural Sciences. Ghent University, Ghent, Belgium.

3. Bulit, J., and Dubos, B. 1990. Botrytis bunch rot and blight. In: Compendium of Grape Diseases. R. C. Pearson and A. C. Goheen, eds. American Phytopathological Society Press, St. Paul, MN.

4. Castillo-Pando, M. S., Nair, N. G., and Wicks, 
T. J. 1997. Inhibition in pycnidial viability of Phomopsis viticola on canes in situ as an aid to reducing inoculum potential of cane and leaf blight disease of grapevines. Australas. Plant Pathol. 26:21-25.

5. Chamberlain, G. C., Willison, R. S., Townsend, J. L., and Ronde, J. H. D. 1964. Two fungi associated with the dead-arm disease of grapes. Can. J. Bot. 42:351-355.

6. Coleman, L. C. 1928. The dead-arm disease of grapes in Ontario. Sci. Agric. 8:281-315.

7. Daykin, M. E., and Milholland, R. D. 1990. Histology of blueberry twig blight caused by Phomopsis vaccinii. Phytopathology 80:736740.

8. Dorworth, C. E., and Callan, B. E. 1996. Manipulation of endophytic fungi to promote their utility as vegetation biocontrol agents. Pages 209-216 in: Endophytic Fungi in Grasses and Woody Plants. S. C. Redlin and L. M. Carris, eds. The American Phytopathological Society Press, St. Paul, MN.

9. Emmett, R. W., Nair, N. G., and Wicks, T. J. 1998. Phomopsis. Pages 211-213 in: Disease and Pests No. 1. Grape Production Series. P. Nicholas, P. A. Magarey, and M. Wachtel, eds. Winetitles, Adelaide, Australia.

10. Erincik, O., and Madden, L. V. 2001. Effect of growth stage on susceptibility of grape berry and rachis tissues to infection by Phomopsis viticola. Plant Dis. 85:517-520.

11. Gubler, W. D., and Leavitt, G. M. 1992. Phomopsis cane and leaf spot. Pages 85-87 in: Grape Pest Management. D. L. Flaherty, L. P. Christensen, W. T. Lanini, J. J. Marois, P. A. Phillips, and L. T. Wilson, eds. Regents of the University of California, Division of Agriculture and Natural Resources, Oakland.

12. Helander, M. L., Neuvonen, S., and Ranta, H.
1996. Natural variation and effects of anthropogenic environmental changes on endophytic fungi in trees. Pages 197-207 in: Endophytic Fungi in Grasses and Woody Plants. S. C. Redlin and L. M. Carris, eds. The American Phytopathological Society Press, St. Paul, MN.

13. Hewitt, W. B., and Pearson, R. C. 1990. Phomopsis cane and leaf spot. Pages 17-18 in: Compendium of Grape Diseases. R. C. Pearson and A. C. Goheen, eds. The American Phytopathological Society Press, St. Paul, MN.

14. Hood, M. E., and Shew, H. D. 1996. Applications of $\mathrm{KOH}$-Aniline blue fluorescence in the study of plant-fungal interactions. Phytopathology 86:704-708.

15. Melanson, D. L., Rawnsley, B., and Scheper, R. W. A. 2002. Molecular detection of Phomopsis taxa 1 and 2 in grapevine canes and buds. Australas. Plant Pathol. 31:67-73.

16. Merrin, S. J., Nair, N. G., and Tarran, J. 1995. Variation in Phomopsis recorded on grapevine in Australia and its taxonomic and biological implications. Australas. Plant Pathol. 24:4456.

17. Moller, W. J., and Kasimatis, A. N. 1981. Further evidence that Eutypa armeniacae-not Phomopsis viticola - incites dead arm symptoms on grape. Plant Dis. 65:429-431.

18. Mostert, L., Crous, P., and Petrini, O. 2000. Endophytic fungi associated with shoots and leaves of Vitis vinifera, with specific reference to the Phomopsis viticola complex. Sydowia 52:46-58.

19. Mostert, L., Crous, P. W., Kang, J., and Phillips, A. J. L. 2001. Species of Phomopsis and a Libertella sp. occurring on grapevines with specific reference to South Africa: morphological, cultural, molecular and pathologi- cal characterisation. Mycologia 93:146-167.

20. Phillips, A. J. L. 1998. Botryosphaeria dothidea and other fungi associated with excoriose and dieback of grapevines in Portugal. J. Phytopathol. 146:327-332.

21. Phillips, A. J. L. 1999. The relationship between Diaporthe perjuncta and Phomopsis viticola on grapevines. Mycologia 91:10011007.

22. Pine, T. S. 1959. Development of the grape dead-arm disease. Phytopathology 49:738-743.

23. Pscheidt, J. W, and Pearson, R. C. 1989. Time of infection and control of Phomopsis fruit rot of grape. Plant Dis. 73:829-833.

24. Reddick, D. 1909. Necrosis of the grapevine. Cornell Univ. Bull. 263:323-342.

25. Scheper, R. W. A., Crane, D. C., Whisson, D L., and Scott, E. S. 2000. The Diaporthe teleomorph of Phomopsis Taxon 1 on grapevine. Mycol. Res. 104:226-231.

26. Taylor, R. H., and Mabbitt, J. M. 1961 Deadarm disease of grapevines. Dep. Agric. Victoria, Australia, Biol. Branch Publ. No. 901 3510/61, 59:157-165.

27. Uddin, W., and Stevenson, K. L. 1997. Pathogenicity of a species of Phomopsis causing a shoot blight on peach in Georgia and evaluation of possible infection courts. Plant Dis 81:983-989.

28. Williamson, P. M., Than, K. A., Sivasithamparam, K., Cowling, W. A., and Edgar, J. A. 1995. Detection of resistance to Diaporthe toxica in asymptomatically infected lupin seedlings based on an immunoassay for phomopsin. Plant Pathol. 44:95-97.

29. Willison, R. S., Chamberlain, G. C., Townshend, J. L., and Ronde, J. H. D. 1965. Epidemiology and control of dead-arm of grapes. Can. J. Bot. 43:901-914 